\title{
ZALECENIA JAKO FORMA OKREŚLANIA WYMOGÓW OCHRONY ŚRODOWISKA
}

\author{
RECOMMENDATIONS AS A FORM \\ OF DETERMINING THE REQUIREMENTS \\ OF ENVIRONMENTAL PROTECTION
}

\section{STRESZCZENIE W JĘZYKU POLSKIM}

Artykuł przedstawia rolę zaleceń, niewiążących aktów prawa Unii Europejskiej, w określaniu wymogów ochrony środowiska. Omawia rolę „prawa miękkiego”, ze szczególnym uwzględnieniem rezolucji Parlamentu Europejskiego dotyczącej jego stosowania i znaczenia. Analizuje zalecenia związane z prawem ochrony środowiska, wydane i opublikowane w ciągu pięciu lat: od roku 2005 do roku 2009. Analizowane zalecenia dotyczą: postępowania z GMO, ochrony przed promieniowaniem jonizującym, ochrony przed szkodliwym działaniem sub-

* Doktor nauk prawnych, kierownik Katedry Administracji Publicznej Wyższej Szkoły Inżynieryjno-Ekonomicznej w Rzeszowie. 
stancji chemicznych, efektywności energetycznej urządzeń, ochrony zwierząt laboratoryjnych, ochrony dzikiej fauny i flory, ochrony przed trwałymi zanieczyszczeniami organicznymi i emisji z transportu miejskiego.

\section{Słowa kluczowe}

Prawo Unii Europejskiej, ochrona środowiska, zalecenia.

\section{STRESZCZENIE W JĘZYKU ANGIELSKIM}

The article discusses the role of the recommendations of legally non-binding European Union legal acts in defining the requirements and standards of environmental protection. It presents the role of the soft law with particular focus on the European Parliament resolution on the soft law implementation and its meaning. The article analyses environmental law requirements published from the year 2005 to 2009 . The requirements concern GMO issues, protection against radiation, protection against toxic and hazardous effects of chemical substances, energy efficiency of equipment, protection of laboratory animals, protection of flora and fauna, and protection against permanent organic pollutants and transport emissions.

\section{Key words}

EU law, environmental protection, requirements.

\section{UWAGI WSTĘPNE}

Zalecenia są nazwanymi aktami niewiążącymi. Do czasu wejścia w życie Traktatu z Lizbony mogły być przyjmowane przez wszystkie instytucje unijne ${ }^{1}$. Zalecenia mają konkretnych

1 Od 1 grudnia 2009 r., zgodnie z Traktatem z Lizbony, kompetencje do przyjmowania zaleceń ma Rada i Komisja Europejska. W szczególnych przypadkach przewidzianych $\mathrm{w}$ Traktatach zalecenia może przyjmować również Europejski Bank Centralny. 
adresatów i dotyczą konkretnych kwestii, co do których wyrażane są stanowiska lub opinie. Moc oddziaływania niewiążących aktów nazwanych (zaleceń i opinii) jest sporna. Twierdzi się, że „państwa członkowskie starają się do nich dostosować, co wynika z autorytetu organów je wydających"2. Na brak jednolitości praktyki Trybunału Sprawiedliwości Unii Europejskiej odniesieniu do skutków prawnych zaleceń zwrócił uwagę W. Czapliński³ W sprawie 70/69 Feram $v$. Komisja Trybunał orzekł, że zalecenia nie mają w ogóle mocy prawnej ${ }^{4}$ Jednak później, w sprawie C-322/88 S. Grimaldi v. Fonds des maladies professionelles wypowiedział się za uwzględnieniem zaleceń przy wykładni prawa wspólnotowego ${ }^{5}$. Trybunał wskazał, że sądy krajowe powinny brać zalecenia pod uwagę, gdy są one pomocne w interpretowaniu środków krajowych przyjętych w procesie implementacji lub uzupełniają wiążące akty prawa unijnego ${ }^{6}$.

Istnieją wyraźne tendencje do mnożenia inicjatyw miękkiego prawa na wszystkich szczeblach polityki UE7 ${ }^{7}$ Zalecenia (i opinie) dla zwiększenia skuteczności oddziaływania publikowane są często w oficjalnym dzienniku urzędowym ${ }^{8}$. Ranga aktów niewiążących rośnie, ponieważ zasada pomocniczości nakazuje ich wykorzystanie zamiast aktów wiążących zawsze gdy to jest możliwe. Szczególna rola przypada tu zaleceniom ${ }^{9}$. Stosowanie zasady pomocniczości jest oceniane przez Radę ds. Oceny Skutków, a swoją opinię w tym zakresie może wyrazić również COSAC ${ }^{10}$.

2 G. Dobrowolski, Europejskie prawo ochrony środowiska (wybrane zagadnienia) z tekstami źródłowymi, Katowice 2003, s. 21.

3 W. Czapliński, Zarys prawa europejskiego, Warszawa 2002, s. 38.

4 Zb. Orz. TE [1971] 227.

5 Zb. Orz. TE [1989] 4407.

6 Efekt tego orzeczenia bywa określany jako „skutek Grimaldi”.

7 Corporate Social Responsibility soft law developments in the European Union, Oxford Pro Bono Publico, University of Oxford 2009, s. 3.

8 Z. Brodecki, Prawo europejskiej integracji, Warszawa 2000, s. 87.

9 C. Mik. Europejskie prawo wspólnotowe. Zagadnienia teorii i praktyki, Warszawa 2002, s. 523.

10 Ang. Conference of Parliamentary Committees for Union Affairs of Parliaments of the European Union - Konferencja Komisji do Spraw Unijnych Parlamentów Unii Europejskiej. 
Komisja corocznie składa Radzie i Parlamentowi Europejskiemu sprawozdanie w sprawie pomocniczości i proporcjonalności ${ }^{11}$.

Z uwagi na fakt, że poziom legislacyjny dyrektyw jest często niezadowalający, m.in. ze względu na nieprecyzyjną terminologię i nie poprawia sytuacji nagminne stosowanie wykładni ustawowej, istnieją poważne trudności z prawidłową implementacją. Jedną z metod ich przezwyciężania jest stosowanie przez Komisje zaleceń. Prawidłowo skonstruowany akt normatywny nie powinien jednak wymagać urzędowego wyjaśnienia ${ }^{12}$. Podkreśla się, że „ponadto jest obowiązkiem Komisji i Rady wydawanie tego rodzaju aktów, a zatem w przypadku naruszenia tego obowiązku można wnieść, zgodnie z art. 232(1) TWE skargę na bezczynność organu. Z wydaniem lub zaniechaniem wydania zaleceń lub wyrażenia opinii traktat wiąże konkretne skutki prawne (art. 104 ust. 8)"13. Komisja w programach prac i programach legislacyjnych sporadycznie planuje wydanie zaleceń ${ }^{14}$.

Parlament Europejski w dniu 4 września 2007 r. przyjął rezolucję w sprawie instytucjonalnych i prawnych skutków stoso-

11 Ostatnie sprawozdanie: COM(2009)504 z 25.09.2009.

12 J. Sommer, Efektywność prawa ochrony środowiska i jej uwarunkowania-problemy udatności jego struktury, Wrocław 2005, s. 148.

13 Stosowanie prawa Unii Europejskiej przez sądy, red. A. Wróbel, Zakamycze 2005, s. 64. Artykuł 232 to po zmianach dokonanych przez Traktat z Lizbony (Dz. U. z 2009 r. Nr 203, poz. 1569) art. 265 Traktatu o funkcjonowaniu Unii Europejskiej (Dz. U. z 2004 r. Nr 90, poz. 864/2 ze zm.; dalej cyt.: TFUE) - jego treść została zmieniona: skarga na bezczynność organu może być wniesiona również, gdy zaniecha działania Rada Europejska i Europejski Bank Centralny, oraz - jak wcześniej - PE, Rada i Komisja. Artykuł 104 ust. 8 to obecnie art. 126 ust. 8 TFUE. Brzmienie ust. 8 nie zostało zmienione: jeżeli Rada stwierdzi, że na jej zalecenie nie podjęto skutecznego działania w oznaczonym terminie, może podać zalecenie do publicznej wiadomości.

14 W „Programie prac Komisji i programie legislacyjnym na 2007 r.” (KOM(2006)629 z 24.10.2006) Komisja zaplanowała wydanie zalecenia w sprawie proporcjonalności pomiędzy kapitałem, a kontrolą w spółkach UE - zalecenie to nie zostało zrealizowane w związku z wynikami oceny jego skutków; w „Programie prac Komisji i programie legislacyjnym na 2008 r.” (KOM(2007)640 z 23.10.2007) Komisja zapowiedziała wydawanie zaleceń dotyczących strategii rozszerzenia oraz wydanie zalecenia w sprawie aktywnej integracji oraz zalecenie Rady w sprawie bezpieczeństwa pacjentów i jakości usług w służbie zdrowia. 
wania instrumentów tzw. „miękkiego prawa”, podając jako jego przykłady zalecenia, białe księgi i konkluzje Rady ${ }^{15}$. Rezolucja stwierdza, że „miękkie prawo” (soft law) jest niejednoznaczne i niebezpieczne i nie należy go stosować w dokumentach instytucji unijnych. „Miękkie prawo” nie ma bowiem doniosłości prawnej ani mocy wiążącej. W ocenie posłów do PE częste stosowanie instrumentów „miękkiego prawa” przesuwa jedyny w swoim rodzaju model Unii w stronę typowej organizacji międzynarodowej. To ostatnie stwierdzenie jest zaskakujące, ponieważ w październiku 2007 na spotkaniu Rady Europejskiej ustalono treść Traktatu z Lizbony, który czyni z Unii organizację międzynarodową.

Parlament wysunął szereg argumentów przemawiających za niestosowaniem prawa miękkiego. Najważniejsze z nich to po pierwsze stwierdzenie, że unijny porządek prawny opiera się na demokracji i rządach prawa, a więc instytucje UE mogą działać jedynie zgodnie z zasadą legalności, czyli w obszarach w których dla ich kompetencji istnieje podstawa prawna i w ramach wyznaczonych uprawnień. Traktatowa podstawa do wydawania zaleceń istnieje. Być może wątpliwości Parlamentu wzbudziły zalecenia, służące instytucjom unijnym do wyrażania swojego zdania lub udzielania informacji dotyczących obszarów, w których UE nie ma kompetencji do stanowienia prawa ${ }^{16}$. Rezolucja zawiera informację, że takie działania były podejmowane w przeszłości oraz, że „prawo miękkie” wykorzystywane było jako środek egzekucji prawa.

Po drugie, w rezolucji PE wskazuje się na niebezpieczeństwo pomijania organów legislacyjnych, nieposzanowania zasad demokracji, praworządności, proporcjonalności i pomocniczości w przypadku, gdy z powodu braku woli politycznej, nie przyjęto wiążącego aktu prawnego, a został on „zastąpiony” przez akt

15 P6_TA(2007)0366 (Dz. U. C 187 E z 24.07.2008).

16 Z. Brodecki w pracy wymienionej w przypisie $\mathrm{nr} 98$ na s. 86-87 podaje, że zalecenia i opinie „Służą [...] instytucjom wspólnotowym do wyrażania ich zdania lub do udzielania informacji w dziedzinach, w których nie mają one kompetencji normatywnych". 
„prawa miękkiego”. Takie działanie byłoby również przekroczeniem uprawnień przez Komisję.

Po trzecie, „prawo miękkie” może tworzyć niekorzystny wizerunek superbiurokracji unijnej, oddalonej od obywatela, wrogo do niego nastawionej i pozbawionej demokratycznych podstaw. Może też być podstawą określonych oczekiwań obywateli, nie mających szans realizacji. Podmioty trzecie nie mają możliwości skutecznej obrony w przypadku niekorzystnych dla nich skutków „prawa miękkiego”, ponieważ art. 230 TWE wykluczał możliwość orzeczenia nieważności zaleceń z powodu braku ich mocy wiążącej. Parlament godzi się jednak z wykorzystaniem „prawa miękkiego”, gdy traktat to wyraźnie przewiduje, i gdy prawo to nie jest wykorzystywane jako substytut aktu prawnego w dziedzinach, w których instytucje unijne mają uprawnienia prawodawcze. Szczególnie wyrażona została akceptacja dla aktów „prawa miękkiego”, które można wykorzystać jako środki wykładni lub prac przygotowawczych, nie wyposażone w skuteczność normatywną. Ponadto, Parlament Europejski wezwał Komisję do wspólnego opracowania sposobu działania zapewniającego udział demokratycznie wybranych organów w przyjmowaniu instrumentów „prawa miękkiego”, jak również zasugerował przyjęcie odpowiedniego porozumienia międzyinstytucjonalnego.

Niniejsza praca przedstawia zalecenia związane z prawem ochrony środowiska wydane i opublikowane w ciągu 5 lat, od roku 2005 do końca roku 2009¹7. Rok 2005 został przyjęty jako pierw-

17 Zalecenia zostały dobrane zgodnie z definicją „prawa ochrony środowiska” zamieszczoną rozporządzeniu Parlamentu Europejskiego i Rady 1367/2006/WE w sprawie zastosowania Konwencji z Aarhus o dostępie do informacji, udziale społeczeństwa w podejmowaniu decyzji oraz dostępie do sprawiedliwości w sprawach dotyczących środowiska do instytucji i organów Wspólnoty (Dz. Urz. UE L 264 z 25.09.2006). Rozporządzenie definiuje „prawo ochrony środowiska" jako przepisy Wspólnoty, przyczyniające się do realizacji celów polityki ochrony środowiska naturalnego określonych w Traktacie. Cele te to: zachowanie, ochrona i poprawa jakości środowiska, ochrona zdrowia, ostrożne i racjonalne wykorzystanie zasobów naturalnych oraz promowanie na płaszczyźnie międzynarodowej środków zmierzających do rozwiązania regionalnych lub światowych problemów środowiska naturalnego. 
szy pełen rok funkcjonowania poszerzonej o dziesięć państw Unii. Sądzić można, że fakt ten przyczynił się do zwiększenia ilości zaleceń, co spowodowane było trudnościami implementacyjnymi w nowych państwach. Tak jednak się nie stało. Zauważyć należy, że znaczna część acquis communautaire implementowana została przez nowe kraje przed przystąpieniem do UE. W 2005 r. wydano w przedmiotowym obszarze dwa zalecenia, w 2006 r. - sześć, w 2007 r. - trzy, w 2008 r. - dwanaście, a w roku 2009 - trzy zalecenia. Jan W. Tkaczyński w spisie unijnych aktów prawnych dotyczących środowiska od 1958 do końca 2008 r., umieścił ponad siedemdziesiąt zaleceń (zaliczając do tego obszaru również akty dotyczące żywności) ${ }^{18}$. Koniec roku 2009 został przyjęty jako data graniczna z uwagi na przeprowadzone wówczas wybory do PE, z czym wiązało się wyłonienie nowego składu Komisji (działającej w tym okresie „na zwolnionych obrotach”).

W praktyce rozwój miękkich norm prawa wspólnotowego dotyczących ochrony środowiska zaczął się zaraz po zakończeniu Konferencji Sztokholmskiej19. Jednak ilość zaleceń związanych z ochroną środowiska, w porównaniu do ilości wydanych w tym obszarze aktów wiążących, jest znikoma. Zalecenia przedstawione zostały przy zastosowaniu podziału na obszary ochrony środowiska, których akty te dotyczą, z zachowaniem chronologii w opisie aktów w poszczególnych obszarach.

\section{ZALECENIA ZWIĄZANE Z OCHRONĄ ŚRODOWISKA}

\subsection{POSTĘPOWANIE Z GMO}

Pierwsze z wydanych w 2005 r. zaleceń dotyczących ochrony środowiska związane było z niezwykle kontrowersyjnym tematem, jakim jest wprowadzanie na rynek GMO. Dnia 31 sierp-

18 J. W. Tkaczyński, Prawo i polityka. Ochrona środowiska naturalnego Unii Europejskiej, Warszawa 2009, s. 157-317.

19 P.-M. Dupuy, Soft Law and the International Law of the Environment, Michigan Journal of International Law, 1991, Vol. 12:420, s. 55. 
nia 2005 r. Komisja wydała decyzję 2005/635/WE w sprawie wprowadzania na rynek, zgodnie z dyrektywą 2001/18/WE Parlamentu Europejskiego i Rady, rzepaku oleistego genetycznie zmodyfikowanego pod kątem tolerancji na herbicyd glifosat ${ }^{20}$. Decyzję uzupełniało zalecenie Komisji 2005/637/WE z dnia 16 sierpnia 2005 r. w sprawie środków, jakie powinien podjąć posiadacz zezwolenia w celu zapobieżenia powstaniu ewentualnej szkody dla zdrowia i środowiska w wypadku przypadkowego uwolnienia rzepaku oleistego genetycznie zmodyfikowanego pod kątem tolerancji na herbicyd glifosat ${ }^{21}$. Zalecenie skierowane zostało do Królestwa Niderlandów, od którego Komisja otrzymała wniosek na wprowadzenie na rynek produktu, w czasie procedury związanej z wydaniem zezwolenia.

Japoński Instytut Badań Ochrony Środowiska przedstawił oficjalną informację o przypadkowym pojawieniu się genetycznie zmodyfikowanego rzepaku oleistego w pobliżu urządzeń portowych. Komisja postanowiła więc, że w celu zapobieżenia wystąpieniu podobnej sytuacji w UE, konieczne jest wydanie specjalnych wytycznych technicznych, towarzyszących decyzji. Wytyczne te zawierają krótki, sześciopunktowy załącznik do zalecenia. Określa on dodatkowe środki, poza przyjętymi przez decyzję 2005/635/WE, które należy podjąć w przypadku wprowadzenia na rynek genetycznie zmodyfikowanego rzepaku. Środki te to informowanie zainteresowanych rolników Unii o wydaniu zezwolenia, planie monitorowania i osobie kontaktowej, do której należy się zwracać w sprawie ewentualnych szkodliwych skutków wprowadzenia na rynek GMO. Komisja przypomina też o istniejących podstawach prawnych do przeprowadzania przez państwa kontroli i dodatkowego monitorowania przypadkowego uwolnienia nasion genetycznie zmodyfikowanego rzepaku oraz określenia prawdopodobnych szkodliwych skutków takiego uwolnienia.

Zalecenie jest wynikiem realizowania zasady ostrożności (ewentualne szkodliwe skutki nie są znane), którą Komisja zdefiniowała w 2005 r. w komunikacie „Projekt deklaracji zasad

20 Dz. Urz. UE L 228 z 3.09.2005.

21 Dz. Urz. UE L 228 z 3.09.2005. 
przewodnich w zakresie zrównoważonego rozwoju”, jako przyjmowanie ostrożnego podejścia dla uniknięcia potencjalnego niebezpieczeństwa dla zdrowia ludzi lub dla środowiska, a także podejmowanie działań zapobiegawczych, w sytuacji istnienia obiektywnych, naukowych wątpliwości ${ }^{22}$.

Zasadę (regułę) ostrożności przywołuje w tekście zalecenie Komisji dla Rady w sprawie udziału Wspólnoty Europejskiej w negocjacjach dotyczących międzynarodowych zasad i procedur w dziedzinie odpowiedzialności i zadośćuczynienia za szkody spowodowane transgranicznymi przewozami zmodyfikowanych organizmów żywych na mocy Protokołu Kartageńskiego ${ }^{23}$ o bezpieczeństwie biologicznym ${ }^{24}$. Zalecenie wykonywało dyspozycję art. 300 ust.1 Traktatu WE ${ }^{25}$. Komisja zalecała Radzie, aby upoważniła ją do udziału w negocjacjach wchodzących w zakres kompetencji Wspólnoty, dotyczących zasad i procedur odnoszących się do odpowiedzialności i zadośćuczynienia za szkody spowodowane transgranicznymi przewozami zmodyfikowanych organizmów żywych, podczas trzech posiedzeń otwartej grupy roboczej prawników i ekspertów technicznych oraz na czwartym posiedzeniu Stron Protokołu. Ponadto Komisja opracowała załącznik do zalecenia zawierający wytyczne negocjacyjne, które Rada miała wydać. Zawierały one wskazania, aby Komisja zapewniła spójność zasad i procedur Protokołu z prawem Wspólnoty, a ponadto aby były one dostosowane do możliwości krajów rozwijających się. W przypadku, gdyby te zasady i procedury sta-

$22 \operatorname{KOM}(2005) 218$ z 25.05.2005.

23 Protokół Kartageński, sporządzony w Montrealu dnia 29 stycznia 2000 r., o bezpieczeństwie biologicznym do Konwencji o różnorodności biologicznej, Dz. U. z 2004 r. Nr 216, poz. 2201.

24 SEK(2006)1135 z 15.09.2006.

25 Artykuł 300 ust.1 Traktatu WE nakazywał Komisji, w przypadku przewidywanego zawarcia umowy między Wspólnotą, a jednym lub kilkoma państwami lub organizacjami międzynarodowymi, udzielenie zaleceń Radzie, która z kolei upoważnia Komisję do rozpoczęcia negocjacji. Artykuł 300 Traktatu WE zastąpiony został przez art.188 TFUE. Komisja nadal przedstawia zalecenia Radzie. Jeżeli umowa dotyczy wyłącznie lub głównie wspólnej polityki zagranicznej i bezpieczeństwa zalecenia przedstawia wysoki przedstawiciel Unii do spraw zagranicznych i polityki bezpieczeństwa., który jest jednocześnie wiceprzewodniczącym Komisji Europejskiej. 
ły się częścią wiążącej umowy, powinna była ona zawierać przepisy umożliwiające Wspólnocie przystąpienie do niej w charakterze strony. Komisja miała też przedstawić Radzie sprawozdanie $\mathrm{z}$ negocjacji zawierające informacje o ewentualnych problemach.

Praktycznie Komisja opracowała wytyczne sama dla siebie, a Rada miała jedynie w sposób formalny je wydać, co nie oznacza, że nie mogła wprowadzić zmian do wytycznych.

\subsection{OCHRONA PRZED PROMIENIOWANIEM JONIZUJĄCYM}

Drugie zalecenie wydane przez Komisję w 2005 r. związane z ochroną środowiska, to zalecenie Komisji 2006/40/Euratom z dnia 15 grudnia 2005 r. w sprawie wytycznych do stosowania rozporządzenia (Euratom) nr 302/2005 w sprawie stosowania zabezpieczeń przyjętych przez Euratom ${ }^{26}$. Rozporządzenie Komisji (Euratom) nr 302/2005 z dnia 8 lutego 2005 r. w sprawie stosowania zabezpieczeń przyjętych przez Euratom określa charakter i zakres wymagań przyjętych w art. 77, 78, 79 i 81 Traktatu Euratom $^{27}$. Wymagania te dotyczą:

- obowiązków państw związanych z eksploatacją rud, materiałów wyjściowych i specjalnych materiałów rozszczepialnych oraz kontrolą przestrzegania zapisów o bezpieczeństwie zamieszczonych w międzynarodowych umowach i zobowiązaniach Wspólnoty,

- zgłaszania Komisji podstawowych parametrów technicznych instalacji do produkcji i innego wykorzystania materiałów rozszczepialnych przez każdego, kto uruchamia lub eksploatuje takie instalacje oraz zatwierdzania przez Komisję technik używanych do przetwarzania paliw jądrowych,

- przekazywania Komisji danych dotyczących eksploatacji i transportu rud, materiałów wyjściowych i specjalnych materiałów rozszczepialnych przez przedsiębiorców oraz

26 Dz. Urz. UE L 28 z 1.02.2006.

27 Dz. Urz. UE L 54 z 28.02.2005; Traktat ustanawiający Europejską Wspólnotę Energii Atomowej, Dz. U. z 2004 r. Nr 90, poz. 864/3 ze zm.; dalej cyt.: Traktat Euratom. 
zawiadamiania o tych faktach władz państwa członkowskiego,

- misji i uprawnień inspektorów Komisji na terenie państw członkowskich.

Artykuł 37 rozporządzenia 302/2005 nałożył na Komisję obowiązek przyjęcia i opublikowania wytycznych w sprawie jego stosowania w formie zaleceń, oraz aktualizowania ich w ścisłej konsultacji z państwami członkowskimi, po otrzymaniu uwag zainteresowanych stron.

Przyjąć można, że jedną z przyczyn uzasadniających wydanie wytycznych było uchylenie rozporządzenia Komisji (Euratom) nr 3227/76 z dnia 19 października 1976 r. dotyczącego stosowania przepisów w sprawie zabezpieczeń Euratomu ${ }^{28}$. Niektóre przepisy uchylonego rozporządzenia określającego charakter i zakres wymagań zawartych w art. 78 i 79 Traktatu Euratom zostały zastąpione przez przepisy rozporządzenia nr 302/2005 o zmienionej treści. Nowe rozporządzenie dotyczy ponadto art. 77 i 81 Traktatu Euratom. Wytyczne nie dotyczą przepisów, które pozostały niezmienione. Do pozostałych artykułów ogłoszono wytyczne odnoszące się do każdego z nich oraz załączników, w efekcie czego powstał akt liczący ponad 50 stron. Struktura wytycznych odpowiada treści rozporządzenia. Niektóre wyjaśnienia są bardzo szczegółowe i zawierają przykłady dokumentów sprawozdawczych. Część wyjaśnień zawiera odwołania do adresów stron internetowych, na których można uzyskać bardziej szczegółowe informacje.

Zalecenie Komisji 2006/715 Euratom z dnia 23 października 2006 r. dostosowujące zalecenie 2000/473/Euratom w sprawie stosowania art. 36 Traktatu Euratom dotyczącego kontrolowania poziomu napromieniowania środowiska naturalnego w celu oceny stopnia narażenia ludności, w związku z przystąpieniem Bułgarii i Rumunii, zostało wydane w związku z Aktem przystąpienia tych państw ${ }^{29}$. Artykuł 56 tego Aktu nakazuje, aby w przypadku, gdy pozostające w mocy po dniu 1 stycznia $2007 \mathrm{r}$.

28 Dz. Urz. UE L 363 z 31.12.1976, zmienione rozporządzeniem (Euratom) nr 2130/93 (Dz. Urz. UE L 191 z 31.07.1993).

29 Dz. Urz. UE L 293 z 24.10.2006. 
akty wymagały w związku z przystąpieniem dostosowań, a dostosowania te nie zostały przewidziane w Akcie lub jego załącznikach, Komisja przyjęła niezbędne akty dostosowawcze, w przypadku gdy przyjmowała akt podstawowy. Zmiana zalecenia 2000/473/Euratom polega jedynie na dopisaniu w załączniku nowoprzyjętych państw i zmianie mapy. Jest to więc zmiana o charakterze formalnym, nieingerująca $\mathrm{w}$ treść merytoryczną zalecenia 2000/473/ Euratom.

Zalecenie Komisji 2006/851/Euratom z dnia 24 października 2006 r. w sprawie zarządzania zasobami finansowymi przeznaczonymi na likwidację instalacji jądrowych, zużytego paliwa i odpadów radioaktywnych realizuje potrzebę większej przejrzystości i harmonizacji zarządzania zasobami finansowymi ${ }^{30}$. Motywy wstępne zalecenia odwołują się do postanowień Traktatu Euratom dotyczących bezpieczeństwa oraz dyrektywy Rady 96/2009/Euratom ustanawiającej podstawowe normy bezpieczeństwa w zakresie ochrony zdrowia pracowników i ogółu społeczeństwa przed zagrożeniami wynikającymi z promieniowania jonizującego ${ }^{31}$ i dyrektywy Rady 85/337/EWG z dnia 27 czerwca 1985 r. w sprawie oceny wpływu wywieranego przez niektóre przedsięwzięcia publiczne i prywatne na środowisko ${ }^{32}$.

Zalecenie proponuje środki gwarantujące we właściwym czasie dostępność odpowiednich kwot na likwidację instalacji jądrowych oraz zarządzanie zużytym paliwem i odpadami radioaktywnymi. Dokument składa się z preambuły (motywów wstępnych) i siedmiu sekcji określających: cel, definicje, likwidację instalacji jądrowych, aspekty instytucjonalne i proceduralne, fundusze likwidacyjne, oszacowanie kosztów likwidacji i wykorzystanie funduszy likwidacyjnych. W procesie likwidacji zalecane jest konsekwentne stosowanie systemowej zasady unijnego prawa ochrony środowiska, jaką jest zasada „zanieczyszczający płaci”. Została ona wypracowana jako metoda alokacji kosztów, związanych z ochroną środowiska przez OECD w 1972 r. Zalece-

30 Dz. Urz. UE L 330 z 28.11.2006.

31 Dz. Urz. UE L 159 z 29.06.1996.

32 Dz.Urz. UEL 175 z 5.07.1985. Dyrektywa zmieniona dyrektywą 2003/35/ WE Parlamentu Europejskiego i Rady (Dz. Urz. UE L 156 z 25.06.2003). 
nia OECD postulują, aby koszty zanieczyszczeń pokrywane były przez zanieczyszczającego, który może je przerzucić na konsumenta. Koszty te nie mogą być subsydiowane przez państwo.

M. Kenig-Witkowska, na podstawie przeglądu stosowania zasady „zanieczyszczający płaci” określiła dwojaki sposób jej interpretacji: 1) zasada związaną jest jedynie z kosztami działań prewencyjnych i walki z zanieczyszczeniami, 2) zasada dotyczy wszystkich kosztów zanieczyszczenia wynikających bezpośrednio lub pośrednio z zanieczyszczenia spowodowanego przez dany podmiot ${ }^{33}$. Przedmiotowe zalecenie Komisji bliższe jest drugiemu z wymienionych sposobów interpretacji zasady. W okresie eksploatacji operatorzy powinni zgromadzić bowiem niezbędne środki na późniejszą likwidację instalacji. Ponadto, jeżeli podczas likwidacji jej koszt okaże się wyższy niż zaplanowany lub fundusz wewnętrzny (zarządzany przez operatora) nie zgromadzi niezbędnych środków, operator ponosi dodatkowe wydatki. Preferowaną opcją jest tworzenie funduszu zewnętrznego, gwarantowanego przez państwo, szczególnie w przypadku nowych instalacji. Odstępstwem od zasady „zanieczyszczający płaci” jest udzielanie pomocy gospodarczej przez UE na likwidację instalacji jądrowych uznanych za nierentowne. Dotyczy to nowych krajów członkowskich i ustalane jest w negocjacjach akcesyjnych. Pomoc ta musi być oceniona w aspekcie traktatowych zasad dotyczących pomocy państwa.

Główne wymogi dotyczące wywozu odpadów promieniotwórczych lub wypalonego paliwa jądrowego do krajów trzecich określa, skierowane do państw członkowskich, zalecenie Komisji 208/956/Euratom z dnia 4 grudnia 2008 r. w sprawie kryteriów wywozu odpadów promieniotwórczych i wypalonego paliwa do krajów trzecich ${ }^{34}$. Zalecenie odwołuje się do postanowień Traktatu Euratom nakazujących Komisji kierowanie do państw członkowskich zaleceń dotyczących harmonizacji przepisów, o ile Traktat wyraźnie to przewiduje lub Komisja uzna je za niezbędne (art. 33 akapit drugi i art. 124 tiret drugi). Bezpośredni nakaz

33 M. M. Kenig- Witkowska, Prawo środowiska Unii Europejskiej. Zagadnienia systemowe, Warszawa 2005, s. 103.

34 Dz. Urz. UE L 338 z 17.12.2008. 
dla Komisji w sprawie określenia kryteriów spełniania wymogów wywozu zamieszczony jest w art.16 ust.2 dyrektywy Rady 2006/117/Euratom w sprawie nadzoru i kontroli nad przemieszczaniem odpadów promieniotwórczych oraz wypalonego paliwa jądrowego ${ }^{35}$.

Podstawowe wymogi zamieszczone w zaleceniu związane z wywozem odpadów promieniotwórczych lub odpadów jądrowych to ustanowienie odpowiednich przepisów krajowych wraz z systemem odpowiedzialności osób trzecich, powołanie niezależnych organów wydających zezwolenia, podział odpowiedzialności między operatorów i organy regulacyjne (z tym, że odpowiedzialność spoczywa głównie na posiadaczu zezwolenia), wdrożenie odpowiednich programów bezpieczeństwa i planów postępowania w sytuacjach kryzysowych, stworzenie środków ochronnych i naprawczych, w tym informowanie zainteresowanych grup społecznych, istnienie wykwalifikowanej kadry oraz stosowanie właściwej sprawozdawczości.

Zalecenie wskazuje kryteria jakie państwa powinny stosować w celu oceny czy państwa trzecie mogą przyjąć odpady. Kryteria główne to członkowstwo w Międzynarodowej Agencji Energii Atomowej oraz ratyfikacja odnośnych konwencji międzynarodowych. Kryteria dodatkowe dotyczą również podpisania właściwych konwencji, ale uwzględnione mogą tu być też kwestie polityczne, gospodarcze, społeczne, etyczne, naukowe i bezpieczeństwa publicznego. Tak szerokie ujęcie tych kryteriów daje państwom UE możliwość praktycznie swobodnego podejmowania decyzji co do wywozu odpadów promieniotwórczych lub wypalonego paliwa jądrowego; kryteria nie są jednoznaczne. Właściwe organy państw członkowskich powinny współpracować w zakresie wymiany informacji na temat stosowania zalecenia.

Cechy referencyjne systemów ewidencji i kontroli NMAC (nuclear material accountancy and control) prowadzonych przez operatorów określa zalecenie Komisji 2009/120/Euratom z dnia 11 lutego 2009 r. w sprawie wdrażania systemu ewidencji i kontroli materiałów jądrowych przez operatorów tych obiektów ${ }^{36}$.

35 Dz. Urz. UE L 337 z 5.12.2006.

36 Dz. Urz. UE L 41 z 12.02.2009. 
Zalecenie odwołuje się do art. 77 i 124 Traktatu Euratom, mówiących o uprawnieniach Komisji w zakresie czuwania nad stosowaniem postanowień Traktatu. Dokument uszczegóławia i dokonuje wykładni przepisów art. 7 rozporządzenia Komisji (Euratom) nr 302/2005. Artykuł ten nakazuje operatorom obiektów jądrowych prowadzenie systemu ewidencji i kontroli materiałów jądrowych i określa wymagania dotyczące systemu. System ma obejmować dokumentację rachunkowości materiałowej i dokumentację ruchową. Dokumentacja musi opierać się na najnowszych normach międzynarodowych lub normach równoważnych. Jest przechowywana przez minimum pięć lat i udostępniana inspektorom Komisji w formie elektronicznej (jeśli w takiej formie jest prowadzona).

Zalecenie informuje, że w 2007 r. Europejskie Stowarzyszenie Badań i Rozwoju w Dziedzinie Zabezpieczeń (ESARDA - European Safeguards Research and Development Association) opublikowało wytyczne dotyczące dobrych praktyk w zakresie systemów ewidencji i kontroli materiałów jądrowych systemu NMAC, odnoszące się do elementów, które można poddać audytowi. Domniemywać można, że Komisja korzystała z tego zalecenia podczas opracowania zalecenia. Zalecenie podzielone jest na siedem sekcji określających cel, terminy i definicje, zarządzanie systemem NMAC, pomiary i kontrolę pomiarów, monitorowanie materiału jądrowego, przetwarzanie i kontrolę danych oraz bilans materiałowy. Większość jego postanowień to wskazania do odpowiedniego prowadzenia dokumentacji, kontroli i określenia obowiązków oraz uprawnień i odpowiedzialności w tym zakresie. Istotnym elementem są również wskazania do odpowiedniego wykonywania niezbędnych pomiarów i przetwarzania danych. Zalecenia te powinny zapewnić zgodność dokumentacji ze stanem faktycznym. 


\subsection{OCHRONA PRZED SZKODLIWYM DZIAEANIEM SUBSTANCJI CHEMICZNYCH}

Rozporządzenie Rady (EWG) nr 793/93 z dnia 23 marca 1993 r. w sprawie oceny i kontroli ryzyk stwarzanych przez istniejące substancje stosowane było do zbierania i upowszechniania informacji o istniejących substancjach oraz oceny ryzyk stwarzanych przez nie dla człowieka i środowiska, w celu lepszego zarządzania tymi ryzykami ${ }^{37}$. Na podstawie art. 11 ust. 2 tego rozporządzenia wyniki oceny ryzyka stwarzanego przez substancje priorytetowe oraz zalecenia działania przyjmowane były przez Komisję, wspieraną przez komitet powołany na podstawie art. 15 tego rozporządzenia oraz publikowane. Wydane na podstawie tego przepisu zalecenie Komisji 2006/283/WE z dnia 11 kwietnia 2006 r. określa środki mające na celu zmniejszenie ryzyka dla określonych substancji wymienionych w wykazach substancji priorytetowych ${ }^{38}$. Wykazy substancji priorytetowych określone są w rozporządzeniach Komisji ${ }^{39}$. Zalecenie skierowane jest do państw członkowskich oraz wszystkich sektorów, które wykorzystują, produkują, przewożą, usuwają lub odzyskują substancje. Zalecane środki to:

- określanie dopuszczalnej wartości emisji niektórych substancji wymienionych $\mathrm{w}$ zaleceniu lub środków równoważnych w pozwoleniach, jak też odpowiednich środków

37 Dz. Urz. UE L 84 z 5.041993; zmienione przez rozporządzenie (WE) nr 1882/2003 (Dz. Urz. UE L 284 z 31.10.2003); uchylone przez rozporządzenie (WE) nr 1907/2006 (Dz. Urz. UE L 396 z 30.12.2006).

38 Zalecenie Komisji z dnia 11 kwietnia 2006 r. w sprawie środków mających na celu zmniejszenie ryzyka dla następujących substancji: ftalany dibutylu; 3,4- dichloroanilina; ftalany diizodecylowy; kwas 1,2 benzenodikarboksylowy; dwu- rozgałęzione C 9-11 estry alkilowe, bogate w C 9; kwas etylenodiaminotetraoctowy; octan metylu; kwas monochlorooctowy; n-Pentan; etylenodiaminotetraoctan tetrasodu (Dz. Urz. UE L 104 z 13.04.2006).

39 Zalecenie dotyczy substancji wymienionych w rozporządzeniach: (WE) nr 1179/94 (Dz. Urz. UE L 131 z 26.05.1994), (WE) nr 2268/95 (Dz. Urz. UE L 231 z 28.09.1995), (WE) nr 143/97 (Dz. Urz. UE L 25 z 161 z 28.01.1997). 
technicznych, tak aby instalacje zaczęły działać do końca października 2007 r. zgodnie z BAT ${ }^{40}$,

- monitorowanie przez państwa członkowskie wdrażania BAT oraz informowanie Komisji o istotnych zmianach,

- ustanawianie przez państwa członkowskie w odniesieniu do dorzeczy środowiskowych norm jakości (EQS) ${ }^{41}$.

- włączenie krajowych ośrodków działających na rzecz redukcji zanieczyszczeń do planów gospodarki wodami w dorzeczach, zgodnie z dyrektywą 2000/60/WE,

- poddanie lokalnych emisji, tam gdzie to właściwe, kontroli zgodności z przepisami krajowymi, w celu wykluczenia jakiegokolwiek ryzyka dla środowiska,

- uwzględnienie przez pracodawców w sektorze budownictwa specyficznych dla sektora wytycznych krajowych, opracowanych w oparciu o niewiążące wytyczne Komisji.

Obowiązek Komisji do opracowania wytycznych wynikał z art.12 ust.2 dyrektywy Rady 98/24/WE z dnia 7 kwietnia 1998 r. w sprawie ochrony zdrowia i bezpieczeństwa pracowników przed ryzykiem związanym ze środkami chemicznymi w miejscu pracy (czternasta dyrektywa szczegółowa w rozumieniu art.16 ust.1 dyrektywy 89/391/EWG) ${ }^{42}$. Wytyczne mają cha-

40 Ang. Best Available Techniques - Najlepsze Dostępne Techniki, zdefiniowane zostały w dyrektywie Rady 96/61/WE z dnia 24 września 1996 r. dotyczącej zintegrowanego zapobiegania zanieczyszczeniom i ich kontroli (Dz. Urz. UE L 257 z 10.10.1996) zmienionej przez dyrektywę 2003/35/WE (Dz. Urz. UE L 156 z 25.06.2003), dyrektywę 2003/87/2WE (Dz. Urz. UE L 275 z 25.10.2003) i rozporządzenie (WE) nr 1882/2003 (Dz. Urz. UE L 284 z 31.10.2003) jako „najbardziej efektywny i zaawansowany etap rozwoju i metod prowadzenia danej działalności, który wskazuje możliwe wykorzystanie poszczególnych technik jako podstawy dla dopuszczalnych wartości emisji mających na celu zapobieganie powstawaniu, a jeżeli jest to możliwe, ogólne ograniczenie emisji i oddziaływania na środowisko naturalne jako całość". Dyrektywa została skodyfikowana i nosi numer 2008/1/WE (Dz. Urz. UE L 24 z 29.01.2008).

41 Ang. Environmental Quality Standards - wprowadzenia środowiskowych norm jakości wymaga dyrektywa Parlamentu Europejskiego i Rady 2000/60/ WE z dnia 23 października 2000 r. ustanawiająca ramy wspólnotowego działania w dziedzinie polityki wodnej (Dz. Urz. UE L 327 z 22.12.2000); dyrektywa zmieniona decyzją 2455/2001/WE (Dz. Urz. UE L 331 z 15.12.2001).

42 Dz. Urz. UE L 131 z 5.05.1998. 
rakter prewencyjny, szkodliwe działanie substancji jest zbadane. Komisja konsultowała się z Komitetem Naukowym ds. Toksyczności, Ekotoksyczności i Środowiska (SCTEE), który wydał opinie dotyczące oceny ryzyka.

Na podstawie rozporządzenia (EWG) nr 793/93 wydanych zostało w 2008 r. kilka zaleceń Komisji w sprawie środków mających na celu zmniejszanie ryzyka powodowanego przez substan$\mathrm{cje}^{43}$. Substancje te zostały uznane za substancje priorytetowe. Zalecane w celu zmniejszenia ryzyka środki są środkami prewencyjnymi, tożsamymi lub zbliżonymi do środków przyjętych przez zalecenie Komisji z dnia 11 kwietnia 2006 r. Dwa zalecenia Komisji dotyczą rtęci.

Jako komunikat Komisji opublikowane zostało zalecenie Komisji dla Rady w sprawie uczestnictwa Wspólnoty Europejskiej w negocjacjach na temat prawnie wiążącego instrumentu dotyczącego rtęci w związku z decyzją 24/3 Rady Zarządzającej Programu Środowiskowego Narodów Zjednoczonych (UNEP) ${ }^{44}$. Celem tego aktu było zapewnienie stałego, spójnego i skutecznego stanowiska UE podczas negocjacji w ramach dwudziestej czwartej sesji UNEP, aby doprowadzić do przyjęcia prawnie wiążącego instrumentu międzynarodowego dotyczącego rtęci. Dokument w części A opisuje kontekst ogólny i istniejące przepisy wspólnotowe. Część B stanowią właściwe zalecenia (wytyczne). Dwa z nich to jedynie informacje o upoważnieniu Komisji przez Radę do udziału w negocjacjach, w porozumieniu z komitetem wyznaczonym przez Radę. Właściwym zaleceniem jest tylko zapis o konieczności ścisłej współpracy Komisji

43 Zalecenie Komisji 2008/447/WE z dnia 30 maja 2008 (Dz. Urz. UE L 156 z 14.06.2008); zalecenie Komisji 2008/446/WE z dnia 29 maja 2008 (Dz. Urz. UE L 156 z 14.06.2008); zalecenie Komisji 2008/454/WE z dnia 30 maja 2008 r. (Dz. Urz. UE L 158 z 18.06.2008); zalecenie Komisji 2008/455/ WE z dnia 30 maja 2008 r. (Dz. Urz. UE L 158 z 18.06.2008); zalecenie Komisji 2008/464/WE z dnia 30 maja 2008 r. (Dz. Urz. UE L 160 z 19.06.2008); zalecenie Komisji 2008/468/WE z dnia 30 maja 2008 r. (Dz. Urz. UE L161 z 20.06.2008); zalecenie Komisji 2008/471/WE z dnia 30 maja 2008 r. (Dz. Urz. UE L 162 z 21.06.2008); zalecenie Komisji 2008/472/EWE z dnia 30 maja 2008 r. (Dz. Urz. UE L z 21.06.2008).

$44 \operatorname{KOM}(2008) 70 \mathrm{z} 12.02 .2008$. 
i państw członkowskich w przypadku spraw dotyczących kompetencji dzielonych, aby prezentować na arenie międzynarodowej jednolite stanowisko.

Zalecenie Komisji 2009/39/WE z dnia 22 grudnia 2008 r. w sprawie bezpiecznego składowania rtęci metalicznej, która nie jest już wykorzystywana w przemyśle chloro-alkalicznym, skierowane jest do przedsiębiorstw należących do stowarzyszenia Euro-Chlor oraz przedsiębiorstw działających w UE, które przyłączą się do dobrowolnej umowy tego stowarzyszenia w sprawie bezpiecznego składowania rtęci ${ }^{45}$. Komisja uznała za zadawalające dobrowolne działania stowarzyszenia Eur-Chlor, zmierzające do bezpiecznego składowania rtęci wycofanej z użytku. Stwierdziła również, że uzupełniają one rozporządzenie Parlamentu Europejskiego i Rady (WE) nr 1102/2008 z dnia 22 października 2008 r. w sprawie zakazu wywozu rtęci metalicznej, niektórych związków i mieszanin rtęci oraz bezpiecznego składowania rtęci metalicznej ${ }^{46}$. Przyjęła, że są one zgodne z kryteriami ustanowionymi w komunikacie Komisji w sprawie umów dotyczących ochrony środowiska naturalnego na szczeblu wspólnotowym, w ramach planu uproszczenia i poprawy środowiska regulacyjnego ${ }^{47}$.

W przedmiotowym dokumencie Komisja zaleca przedsiębiorstwom należącym do Euro-Chlor wykazanie szczególnej dbałości przy wyborze miejsca składowania rtęci wycofanej z użytku, posiadanie umów z mającymi odpowiednie upoważnienia zarządcami składowisk oraz przestrzeganie wysokich standardów technicznych dotyczących składowania, a także prac przygotowawczych do niego. Ponadto zaleca stowarzyszeniu Euro-Chlor przekazywanie corocznych danych o rtęci wycofanej z użytku. 


\subsection{EFEKTYWNOŚCI ENERGETYCZNA URZĄDZEŃ}

Zalecenie Komisji dla Rady w sprawie upoważnienia Komisji do rozpoczęcia negocjacji dotyczących umowy między rządem Stanów Zjednoczonych Ameryki, a Wspólnotą Europejską w sprawie koordynacji programów etykietowania urządzeń biurowych pod względem efektywności energetycznej związane jest z rozpoczęciem negocjacji o przedłużenie na pięć lat umowy o wspólnej realizacji programu ${ }^{48}$. Od 2001 r. Wspólnota i USA razem realizowały na podstawie umowy program Energy Star. Komisja, uwzględniając opinie zainteresowanych stron oraz doświadczenia zdobyte $\mathrm{w}$ trakcie realizacji programu, zaleciła jego dalsze prowadzenie. Dokument przedstawia podstawy i cel proponowanej umowy, informacje o programie, przepisy obowiązujące w dziedzinie, której dotyczy umowa oraz informuje o przeprowadzonych z zainteresowanymi stronami konsultacjach. Wyjaśnia również powody, dla których proponuje odnowienie umowy Energy Star z rządem USA.

Komisja zaleciła upoważnienie jej przez Radę do rozpoczęcia negocjacji umowy oraz powołanie komitetu wspierającego dla potrzeb negocjacji. Załącznik do zalecenia zawierał dyrektywy negocjacyjne. Komisja zaproponowała, aby Rada wydała dyrektywy negocjacyjne jako wytyczne do celów negocjacji. Komisja przedstawiła propozycje zapisów umowy wraz z zapewnieniem, że zostały one umieszczone w projekcie umowy, sporządzonym w trakcie sondażowych rozmów z USA. Propozycje te obejmowały: zasady ogólne, definicje, postanowienia dotyczące zarządzania programem, zasady uczestnictwa, postanowienia związane z koordynacją oraz rejestracją znaków programu, postanowienia ogólne i warunki wejścia w życie i rozwiązania umowy. Logo, wytyczne jego stosowania oraz wspólne specyfikacje techniczne dla sprzętu objętego umową określono w załącznikach. 


\subsection{OCHRONA ZWIERZĄT LABORATORYJNYCH}

Zalecenie Komisji 2006/406/WE z dnia 7 czerwca 2006 r. ustanawiające wytyczne w zakresie stosowania oznaczeń wskazujących na brak testów na zwierzętach zgodnie z dyrektywą Rady 76/768/EWG skierowane jest do producentów i osób odpowiedzialnych za wprowadzenie na rynek produktów kosmetycznych, którzy chcą umieścić na produktach odpowiednie oznaczenia ${ }^{49}$. Taką możliwość przewiduje art. 6 ust 3 dyrektywy Rady 76/768/EWG z dnia 27 lipca 1976 r. w sprawie zbliżenia ustawodawstw Państw Członkowskich dotyczących produktów kosmetycznych ${ }^{50}$. Komisja uzasadniła wydanie zalecenia koniecznością zapewnienia stosowania wspólnych kryteriów dla oznaczeń, ich jednolitego rozumienia oraz zapewnienia, że nie będą one wprowadzać w błąd i prowadzić do nieuczciwej konkurencji. Zalecenie ma też ułatwić zrozumienie art. 6 ust. 3 dyrektywy 76/768/EWG i ułatwić jego jednolite wdrożenie przez organy kontroli. Stwierdzenie to wskazuje, że Komisja traktuje zalecenie jako specyficzny rodzaj wykładni. Komisja informuje również, że właściwe wdrożenie normy zawartej w wymienionym artykule pozwoli zapobiec zakłóceniom na rynku wewnętrznym. Takie podejście czyni z zalecenia prewencyjny środek ochronny rynku wewnętrznego.

Zalecenie przypomina, że nie istnieje obowiązek umieszczania oznakowania informującego o nieprzeprowadzaniu testów na zwierzętach, a każda osoba umieszczająca je na produkcie może sama ustalić jego treść i elementy graficzne. Definiuje pojęcia użyte w art. 6 ust 3 akapit 2 dyrektywy Rady 76/768/EWG. Informuje, że ciężar dowodu o niestosowaniu testów spoczywa na osobie, która umieściła oznaczenie na produkcie i w związku z tym wszelkie istotne informacje muszą być zawsze dostępne dla kontroli.

Wykorzystywanie zwierząt do celów doświadczalnych jest konieczne i nic nie wskazuje na to, że uda się w najbliższym cza-

49 Dz. Urz. UE L 158 z 10.06.2006.

50 Dz. Urz. UE L 262 z 27.09.1976. Dyrektywa była ponad 50 razy zmieniana. 
sie z tego zrezygnować. W celu ochrony zwierząt wykorzystywanych $\mathrm{w}$ procedurach, które mogą spowodować ból, cierpienie, silny niepokój lub trwałe uszkodzenie oraz by zapewnić, tam gdzie to jest nieuniknione, ograniczenie do minimum niekorzystnych oddziaływań, państwa Rady Europy przyjęły 18 marca 1986 r. Europejską konwencję w sprawie ochrony zwierząt kręgowych wykorzystywanych do celów doświadczalnych i innych celów naukowych. Postanowienia tej konwencji do prawa wspólnotowego wdrożyła dyrektywa Rady 806/609/EWG z dnia 24 listopada 1986 r. w sprawie wdrożenia przepisów ustawowych, wykonawczych i administracyjnych państw członkowskich dotyczących ochrony zwierząt wykorzystywanych do celów doświadczalnych i innych celów naukowych ${ }^{51}$. Dodatek A do Konwencji wdrożony został przez załącznik II do dyrektywy 86/609/EWG. Dodatek ten został zmieniony w czerwcu 2006 r. Komisja uznała, że wytyczne zamieszczone w zmienionym dodatku A powinny być ujęte $\mathrm{w}$ formule zalecenia. 18 czerwca 2007 r. przyjęła zalecenie 2007/526/WE w sprawie wytycznych dotyczących trzymania zwierząt wykorzystywanych do celów doświadczalnych i innych celów naukowych i opieki nad tymi zwierzętami ${ }^{52}$. Jako podstawę traktatową wydania zalecenia przyjęto art. 211, tiret drugie Traktatu WE ${ }^{53}$. Motywy wstępne zalecenia wskazują też na akty ustanawiające standardy ochrony zwierząt: dyrektywę Rady 98/58/WE z dnia 20 lipca 1998 r. dotyczącą ochrony zwierząt hodowlanych ${ }^{54}$ i rozporządzenie Rady (WE) nr 1/2005 z dnia 22 grudnia 2004 r. w sprawie ochrony zwierząt podczas transportu i związanych z tym działań oraz zmieniające dyrektywy 64/432/EWG i 93/119/WE oraz rozporządzenie (WE) nr $1255 / 97^{55}$.

Komisja zaleca państwom członkowskim zastosowanie się do wytycznych określonych w załączniku do zalecenia oraz po-

51 Dz. Urz. UE L 358 z 18.12.1986. Dyrektywa zmieniona dyrektywą 2003/65/WE (Dz. Urz. UE L 230 z 16.09.2003).

52 Dz. Urz. UE L 197 z 30.07.2007.

53 Patrz przypis 20.

54 Dz. Urz. UE L 221 z 8.08.1998. Dyrektywa zmieniona rozporządzeniem Rady (WE) nr 806/2003 (Dz. Urz. UE L 122 z 16.05.2003).

55 Dz. Urz. UE L 3 z 5.01.2005. 
informowanie jej o działaniach podjętych $\mathrm{w}$ tym zakresie $\mathrm{w}$ terminie do 15 czerwca 2008 r. Załącznik zawiera rozdział ogólny dotyczący obiektów, warunków bytowania zwierząt i ich kontroli, szkoleń osób odpowiedzialnych oraz rozdział szczególny, poświęcony indywidualnym gatunkom: gryzoniom, królikom, kotom, psom, fretkom, zwierzętom naczelnym, zwierzętom gospodarskim, świnkom miniaturowym, ptakom i płazom. Tekst wytycznych poświęcony zwierzętom naczelnym, obok opisów techniczno- funkcjonalnych zwraca uwagę na problemy stwarzane przez trzymanie tych zwierząt w warunkach laboratoryjnych. Zwierzęta naczelne mają bowiem zaawansowane zdolności poznawcze, złożony zmysł poszukiwania pożywienia oraz wykształcone zachowania społeczne w grupie.

\subsection{OCHRONA DZIKIEJ FAUNY I FLORY}

Konwencję o międzynarodowym handlu dzikimi zwierzętami i roślinami gatunków zagrożonych wyginięciem (CITES) ${ }^{56}$ wykonuje rozporządzenie Rady (WE) nr 338/97 z dnia 9 grudnia 1996 r. w sprawie ochrony dzikiej fauny i flory w drodze regulacji handlu nimi ${ }^{57}$.

Rozporządzenie powołało Grupę do spraw Realizacji złożoną z przedstawicieli organów państw członkowskich pod przewodnictwem przedstawiciela Komisji oraz komitet wspomagający. W wyniku dyskusji tych struktur pomocniczo-doradczych wypracowano katalog działań, które państwa powinny podjąć w celu ułatwienia realizacji rozporządzenia. Ten zestaw działań stanowi treść zalecenia Komisji z dnia 13 czerwca 2007 r. okre-

56 Dz. U. z 1991 r. Nr 27, poz. 112.

57 Dz. Urz. UE L 61 z 3.03.1997. Rozporządzenie do dnia wydania omawianego zalecenia zmieniane było 11 razy. W późniejszych latach wydano również inne akty wdrażające Konwencję: rozporządzenie (WE) nr 1331/2005 (Dz. Urz. UE L 215 z 19,.082008), rozporządzenie (WE) nr 865/2006 (Dz. Urz. UE L 166 z 19.06.2006), rozporządzenie(WE) nr 1037/2007 (Dz. Urz. UE L 238 z 19.07.2007). UE nie jest stroną CITES, a posiada jedynie zgodnie z art. XI Konwencji status obserwatora przy Konferencji Stron. Sygnatariuszami Konwencji są wszystkie państwa UE; podczas Konferencji Stron państwa UE głosują zgodnie z ustaleniami które zapadają na spotkaniach organizowanych przez KE. 
ślającego działania dotyczące wykonania rozporządzenia Rady (WE) nr 338/97 w sprawie ochrony gatunków dzikiej fauny i flory $\mathrm{w}$ drodze regulacji handlu nimi ${ }^{58}$. Dotyczą one zwiększenia skuteczności egzekwowania prawa oraz wzmocnienia współpracy i efektywności wymiany informacji.

Działania zalecane w pierwszym z wymienionych obszarów to przyjęcie krajowych planów koordynacji egzekwowania prawa, zagwarantowanie środków dla skuteczności pracy organów ścigania, zagwarantowanie stosowania odpowiednich sankcji, zgodnie z orzecznictwem Trybunału Sprawiedliwości ${ }^{59}$, kontrole hodowców i właścicieli, korzystanie z oceny ryzyka i działań wywiadowczych oraz zagwarantowanie dostępności obiektów i urządzeń do tymczasowej opieki nad skonfiskowanymi żywymi okazami gatunków. W celu wzmocnienia współpracy i efektywności wymiany informacji Komisja zaleciła m.in.: ustanowienie procedur koordynacji egzekwowania prawa, ułatwianie dostępu organom ścigania do zasobów i kanałów komunikacji, ustanowienia krajowych punktów kontaktowych, korzystanie z fachowej wiedzy Europejskiego Biura ds. Zwalczania Nadużyć Finansowych (OLAF) i wzmacnianie współpracy między regionami.

\subsection{OCHRONA PRZED TRWAEYMI ZANIECZYSZCZENIAMI ORGANICZNYMI}

Konwencja sztokholmska w sprawie trwałych zanieczyszczeń organicznych (POPs) ${ }^{60}$ określa trzy rodzaje działań mających na celu: redukcję lub wyeliminowanie uwolnień POPs z za-

58 Dz. Urz. UE L 159 z 20.06.2007.

59 Do czasu wydania zalecenia TS UE wydał dwa orzeczenia w trybie prejudycjalnym dotyczące stosowania rozporządzenia 338/97: sprawy połączone C-338/97, C-344/97, C-390/97 (Zb. Orz. TE [1999] I-03319); sprawa C-219/07 (Zb. Orz. TE [2008] I-04475).Trzecie orzeczenie, w trybie prejudycjalnym w sprawie C-344/08 (Zb. Orz. TE [2009] I-7033) wydane zostało w 2009 r. na wniosek Sądu Rejonowego w Kościanie i dotyczyło dowodu pozyskania okazów zgodnie z prawem, ciężaru dowodu, domniemania niewinności i prawa do obrony.

60 Dz. U. z 2009 r. Nr 14, poz. 76; ang. persistent organic pollutants. 
mierzonej produkcji i stosowania, ograniczenie lub eliminację uwolnień z niezamierzonej produkcji, ograniczenie lub wyeliminowanie uwolnień ze zmagazynowanych zapasów i odpadów. Konwencja weszła w życie 17 maja 2004 r. UE oraz większość państw członkowskich jest jej stronami. W art. 1 tej konwencji odwołano się do zasady przezorności określonej w zasadzie 15 Deklaracji z Rio. Odwołanie się w zasadzie 15 Deklaracji do „braku całkowitej naukowej pewności” czyni tę zasadę bliższą zasadzie (regule) ostrożności, niż zasadzie prewencji. Każda ze stron konwencji jest uprawniona do złożenia Sekretariatowi wniosku o umieszczenie substancji w wykazach do niej załączonych. Wniosek taki, w imieniu Wspólnoty i państw członkowskich-stron konwencji, Komisja przedłożyła w 2005 i 2006 r. ${ }^{61}$

Według dostępnej wiedzy endosulfan i trifluralina mają cechy trwałych zanieczyszczeń organicznych - przyjęto środki wspólnotowe zmierzające do ich całkowitego wycofania z obrotu, odpowiednio do końca 2007 i 2008 r. Komisja uznała jednak, że ze względu na możliwość przemieszczania się tych substancji na duże odległości, środki krajowe i unijne nie zapewnią wysokiego poziomu ochrony środowiska. Niezbędne jest więc zastosowanie instrumentu międzynarodowego. W tym celu Komisja wydała zalecenie dla Rady dotyczące wniosków, przedstawionych przez Wspólnotę Europejską i państwa członkowskie, w sprawie zmiany załącznika A do konwencji sztokholmskiej w sprawie trwałych zanieczyszczeń organicznych ${ }^{62}$. Komisja, zgodnie z przyjętą procedurą, zaleciła Radzie, aby ją upoważniła do przedłożenia Sekretariatowi wniosku o umieszczenie tych dwóch substancji w załączniku do tej konwencji. Równocześnie Komisja i państwa członkowskie miały przedłożyć wszelkie dostępne informacje, istotne dla poparcia wniosku.

Z zalecenia wynika, że 9 stycznia 2007 r. w ramach pracy Grupy Roboczej ds. Międzynarodowych Zagadnień Środowiska Naturalnego wezwała ona państwa członkowskie do szybkiego ratyfikowania konwencji, zgodnie z zasadą jednolitego stano-

61 Wniosek dotyczył: heksabromobifenylu, chlorodekon, eteru oktabromodifenylu, pentachlorobenzen oraz krótkołańcuchowych chlorowanych parafin.

62 SEK(2007)972 z 11.07.2007. 
wiska Wspólnoty na forum międzynarodowym. Podobną treść zawiera zalecenie Komisji dla Rady w sprawie wniosków składanych w imieniu Wspólnoty Europejskiej i państw członkowskich, dotyczących zmiany załącznika I do Protokołu w sprawie trwałych zanieczyszczeń organicznych do Konwencji EKG ONZ w sprawie transgranicznego zanieczyszczenia powietrza na dalekie odległości ${ }^{63}$. Zmiana Protokołu dotyczy, tak jak w przypadku zmiany załącznika do Konwencji sztokholmskiej, umieszczenia w nim dwóch substancji: endosulfanu i trifluraliny.

\subsection{OCHRONA PRZED EMISJAMI Z TRANSPORTU MORSKIEGO}

Celem zalecenia Komisji 2009/1020/UE z dnia 21 grudnia 2009 r. w sprawie bezpiecznego wdrożenia stosowania paliwa o niskiej zawartości siarki przez statki cumujące w portach Wspólnoty jest wskazanie i rekomendacja państwom członkowskim działań zmierzających do zredukowania emisji dwutlenku siarki $^{64}$. Traktatową podstawą wydania zalecenia jest art. 292 Traktatu o funkcjonowaniu Unii Europejskiej, zgodnie z którym zalecenia przyjmuje Rada, Komisja, a w szczególnych przypadkach również EBC. Wskazówki zamieszczone w zaleceniu mają zastosowanie przy wykonywaniu przepisów dyrektywy Rady 1999/32/WE z dnia 26 kwietnia 1999 r. odnoszącej się do redukcji zawartości siarki w niektórych paliwach ciekłych oraz zmieniającej dyrektywę 93/12/WE ${ }^{65}$.

Artykuł 4b tej dyrektywy ustanawia maksymalną zawartość siarki w paliwach żeglugowych stosowanych w statkach zawijających do portów UE, a art. 6. nakazuje państwom pobie-

$63 \mathrm{KOM}(2008) 413$ z 1.07.2008. Konwencja w sprawie transgranicznego zanieczyszczania powietrza na dalekie odległości, sporządzona w Genewie dnia 13 listopada 1979 r., Dz. U. z 1985 r. Nr 60, poz. 311.

64 Dz. Urz. UE L 348 z 29.12.2009.

65 Dz. Urz. UE L 121 z 11.05.1999. Dyrektywa zmieniona przez rozporządzenie (WE) nr 1882/2003 (Dz. Urz. UE L 284 z 31.10.2003), dyrektywę 2005/33/WE (Dz. Urz. UE L 191 z 22.07.2005), rozporządzenie (WE) nr 219/2009 (Dz. Urz. UE L 87 z 31.03.2009) i dyrektywę 2009/30/WE (Dz. Urz. UE L 140 z 5.06.2009). 
ranie próbek i sprawdzanie zawartości siarki w paliwie. Komisja zaleca państwom, aby żądały od statków cumujących w portach UE, które nie spełniają wymogów dotyczących stosowanego paliwa, przedstawienia szczegółowych dowodów na podejmowanie działań dążących do osiągnięcia zgodności z przepisami. Domniemywać można, że żądanie to powinno być skierowane do kapitana. Zalecenie wymienia jako dowody: umowę z producentem i zatwierdzony plan modernizacji statku, określający datę dostosowania i certyfikacji. Zatwierdzony plan powinien być brany pod uwagę przy określaniu sankcji za nieprzestrzeganie przepisów dyrektywy 1999/32/WE ${ }^{66}$. Zalecenie wskazuje również na podejmowanie przez państwa działań uwrażliwiających właścicieli statków, operatorów i marynarzy na ryzyko niebezpieczeństwa zmiany paliwa przy braku dostosowania układu paliwowego statku.

\section{PODSUMOWANIE}

Przedstawione zalecenia odnoszące się do aktów, których celem jest ochrona środowiska, są zaleceniami wydanymi przez instytucję, jaką jest Komisja. Ich wydanie nie było planowane w rocznych programach prac Komisji. Opracowywane są więc w miarę potrzeb określonych podczas bieżących prac. W komunikacie Komisji dla Parlamentu Europejskiego, Rady, Europejskiego Komitetu Ekonomiczno-Społecznego i Komitetu Regionów w sprawie wdrażania unijnego prawa ochrony środowiska również nie uwzględniono wprost zaleceń jako środków skutecznego wdrażania prawa ochrony środowiska UE ${ }^{67}$. Domniemywać można jednak, że zapowiedziane w komunikacie wytyczne, które mają być wydawane „w celu zapobieżenia sporom interpre-

66 Zgodnie z art. 11 dyrektywy 1999/32/WE skuteczne, proporcjonalne i odstraszające kary za naruszenie krajowych przepisów ustanowionych podczas implementacji ustalają państwa członkowskie.

$67 \mathrm{KOM}(2008) 773 \mathrm{z}$ 18.11.2008. 
tacyjnym i niewłaściwemu zrozumieniu”, będą miały charakter zaleceń.

Zalecenia skierowane są do Rady, państw członkowskich lub konkretnej grupy przedsiębiorstw. Stanowią środki wykładni teleologicznej i systematycznej, przy czym zazwyczaj interpretują rozszerzająco przepisy prawa wtórnego, proponując dodatkowe środki osiągnięcia założonego celu dyrektywy lub rozporządzenia. W przypadku dyrektyw zalecenia są środkiem uzupełniającym harmonizację, zmniejszającym jednak niekiedy margines swobody przy implementacji. Jedno z przedstawionych zaleceń (2006/715 Euratom) dostosowuje jedynie wcześniejsze zalecenia w związku z przystąpieniem nowych państw; nie uzupełnia przy tym zasadniczej treści aktu wcześniejszego.

Konstrukcja zaleceń jest podobna. Składają się z motywów wstępnych podających podstawę prawną ich wydania (prawo pierwotne), przepis rozporządzenia lub dyrektywy do którego się odnoszą, jak również wyjaśniających cel wydania aktu oraz „właściwych zaleceń”, czyli wytycznych. Stopień szczegółowości wytycznych jest różny. Komisja we wstępnej części zalecenia zazwyczaj przywoływała art. 211 tiret drugie Traktatu WE, zobowiązujący ją do czuwania nad stosowaniem postanowień powziętych przez instytucje na jego podstawie ${ }^{68}$ lub przepisy Traktatu Euratom. Niektóre zalecenia zawierają słowniczek pojęć, które nie zostały zdefiniowane $\mathrm{w}$ akcie powszechnie obowiązującym, a Komisja uznała, że ich jednolita interpretacja jest konieczna. Treść przedstawionych zaleceń jest jednoznaczna, zwięzła i precyzyjna, nie zawiera przy tym zbędnych elementów.

Zalecenia powinny zapewniać rzeczywistą skuteczność prawa unijnego. Zapewnią ją jedynie wtedy, gdy wszystkie państwa członkowskie zastosują się do zalecenia, w duchu orzeczenia w sprawie Grimaldi. W obszarze ochrony środowiska stosowanie zaleceń przez wszystkie państwa członkowskie jest szczególnie ważne, ponieważ nie tylko umacnia jednolity rynek, ale zwiększa skuteczność ochrony środowiska, którego granice

68 Traktat z Lizbony uchylił art. 211 Traktatu WE. Obecnie zastępuje go art. 17 Traktatu o Unii Europejskiej (Dz. U. z 2004 r. Nr 90, poz. 864/30 ze zm.) dotyczący funkcjonowania, kompetencji, składu i odpowiedzialności Komisji. 
administracyjne nie dotyczą w sposób naturalny. Brak sankcji za nieprzestrzeganie zaleceń może być przyczyną ich pomijania, ze szkodą dla ochrony środowiska.

Z dużym prawdopodobieństwem domniemywać można, że wprowadzone przez Traktat lizboński akty delegowane i wykonawcze zmniejszą ilość wydawanych przez Komisję zaleceń, z niewątpliwą korzyścią dla środowiska i ku zadowoleniu Parlamentu Europejskiego.

\section{BIBLIOGRAFIA}

Brodecki Z., Prawo europejskiej integracji, Warszawa 2000.

Corporate Social Responsibility soft law developments in the European Union, Oxford Pro Bono Publico, University of Oxford 2009.

Czapliński W., Zarys prawa europejskiego, Warszawa 2002.

Dobrowolski G., Europejskie prawo ochrony środowiska (wybrane zagadnienia) z tekstami źródłowymi, Katowice 2003.

Dupuy P.-M., Soft Law and the International Law of the Environment, Michigan Journal of International Law, 1991, Vol. 12:420.

Kenig-Witkowska M. M., Prawo środowiska Unii Europejskiej. Zagadnienia systemowe, Warszawa 2005.

Mik C., Europejskie prawo wspólnotowe. Zagadnienia teorii i praktyki, Warszawa 2002.

Sommer J., Efektywność prawa ochrony środowiska i jej uwarunkowania-problemy udatności jego struktury, Wrocław 2005.

Stosowanie prawa Unii Europejskiej przez sqdy, red. A. Wróbel, Kraków 2005.

Tkaczyński J. W., Prawo i polityka. Ochrona środowiska naturalnego Unii Europejskiej, Warszawa 2009.

Kontakt e-mail:

erechemla@wp.pl 